\title{
Original Article \\ An Analysis of Land use Change and the Workers' Perception towards Changes from 2007-2017: A Case in Nam Tu Liem District, Hanoi, Vietnam
}

\author{
Pauline V. Hostalero ${ }^{1, *}$, Nguyen Thi $\mathrm{Ha}^{2}$ \\ ${ }^{1}$ Advanced Education Program, Thai Nguyen University of Agriculture and Forestry \\ Thai Nguyen City, Thai Nguyen, Vietnam \\ ${ }^{2}$ VNU University of Science, 334 Nguyen Trai, Hanoi, Vietnam
}

Received 13 May 2019

Revised 20 July 2019; Accepted 11 August 2019

\begin{abstract}
Land use change has been assessed widely using Remote Sensing (RS) and Geographic Information System (GIS) techniques. The analysis of land use change was done by detecting land cover change. A study about land cover change, along with the self-employed workers' perception towards changes between 2007 and 2017 were carried out in Nam Tu Liem District, Hanoi, Vietnam. The result of the study shows that the built-up lands have increased and remained to be the dominant land cover types in 2017. The agriculture has been declining mainly due to conversion into built-up land. Other land type including water, bare land, and vegetation have shown slight changes throughout the years. Overall changes from 2007 to 2017 shown that built-up land gained the most and agriculture land lost the most. On the other hand, the perception study's major findings indicate that about two-thirds (69\%) of respondents are aware of changes. However, almost one-third (31\%) are unaware of the said topic. There are several factors that may affect the awareness of selfemployed workers which will be cursory discussed in the study. This study in Nam Tu Liem District is a first step to determine and understand the major driving factors and their impacts on the land use changes in the area. A detailed land use/cover change study and a larger population size for perception studies are recommended in order for the government to formulate policies to achieve sustainable development.
\end{abstract}

Keywords: Land use change, urbanization, change detection, remote sensing, geographic information system, awareness.

\footnotetext{
* Corresponding author.

E-mail address: paulinehostalero@gmail.com

https://doi.org/10.25073/2588-1094/vnuees.4391
} 


\section{Introduction}

Every country in the World is currently facing certain challenges in their own environment, economy, and civilization. Land use/land cover change (LULCC) is considered the major driver of these challenges due to urbanization [1]. Correspondingly, Vietnam has experienced rapid economic growth during the 1980s to 2000s which had caused uncontrolled and intensive urban expansion, especially in Hanoi, the capital of Vietnam [2]. Moreover, urban areas in Vietnam have expanded spatially by $2.8 \%$ particularly in the western and the northern side of the existing urban area of Hanoi [3]. Since 1986 to present-day, it is noticeable that Vietnam's economy has progressed and has been progressing. Moreover, within 1975 to 2015, Hanoi's urban population has grown from 1.4 million to 7.6 million people [4]. Due to massive disturbance of the economic growth to the environment, the Vietnam government officially implemented a proposed "Master plan of Hanoi 2030, Vision to 2050" or HMP in 2011 [5], which goal is to transform Hanoi into a smart city [5]. In order to achieve the HMP goal, some area of Hanoi will undergo in another spatial development which also means, the existing urban area will be expanded [6]. One of Hanoi's districts, Nam Tu Liem, will be affected by the said Master Plan, which once was one of Hanoi's suburban areas that was announced to be an urban area in 2013 [7]. By these happenings, Nam Tu Liem is expected to be experiencing changes in land use/land cover (LULC).

Land use and land cover changes are the extensive and rapid processes which are primarily induced by and a product of natural and socio-economic factors [8]. These changes are primarily induced by biophysical $[9,10]$, socio-economical [10, 11], and institutional factors [11]. Moreover, these changes in LULC could consecutively affect the surroundings [12] and people [13, 14]. Intense urbanization is currently putting weight on the environment causing land declination [15], forest and habitat destruction [16], pollution [16, 17], variation in spatiotemporal patterns [18], etc. Moreover, land cover change has an important role for the society, especially for the workers. At the present time, people that are living in urban areas like Hoan Kiem and Ba Dinh Districts, which are the central cities of Hanoi, noticeably have advantages that are not experienced by almost the people residing in rural area [19]. Besides, chances of employment and opportunities for business are frequently bigger in urban than rural areas and this is one of the major reasons why people move to and stay in the cities [20]. Urban areas have higher levels of safety, security and services associated with leisure, education, health and standard of living [19]. Also, it usually provides overall quality of society's living standards compared to suburban and rural areas [19]. However, rapid urbanization also put so much weight on people's lifestyle, referring to the worsening traffic congestion, deteriorating environment, and further impacts caused by continuing urbanization and changes in land use [21].

The workers and the society are a significant part of the whole progression of the world, which is one of the reasons why LULCC happens, in order to do good for the standard of living of people [19], as well for the country's economy [22]. However, it sometimes takes a negative effect in some environmental factors which affect other sectors such as humans' health, biodiversity, etc. [13, 14]. Furthermore, to examine if land use change (LUC) certainly occurred within the district, land cover change (LCC) detection using Geographic Information System (GIS) tool and a short LCC awareness study were done.

The aims of the research are to focus on analyzing LCC detection in Nam Tu Liem District and have a short knowledge on workers, particularly the self-employed workers' awareness towards LCC within the district. In order to achieve this aim, the following objectives will be addressed: to assess and analyze LCC in Nam Tu Liem District within 2007-2017; to know the extent of local worker's awareness regarding LCC; to form a vision of what the individual wants their community to 
become in the succeeding years; to find solutions and mitigations for the occurring issues brought by the LCC; and to find patterns how the LCC and social awareness are related. Significant relationship between the spatial and social data will not be included in this study.

\section{Materials and methods}

\subsection{Study area}

Nam Tu Liem, which is also called as the South Tu Liem, is located in the west of Hanoi central districts, Hoan Kiem and Ba Dinh. Nam $\mathrm{Tu}$ Liem is established by the government in 2013 under the Resolution No. 132/NQ-CP which states the adjustment of Tu Liem District into two new separate urban districts: Nam Tu Liem District, and Bac Tu Liem District [23]. Nam Tu Liem has an area of approximately 3,200 hectares and has a population of approximately 233,000 [24]. The district comprises of ten wards, including Trung Van, Dai Mo, Tay Mo, Me Tri, Phu Do, My Dinh 1, My Dinh 2, Cau Dien, Phuong Canh, and Xuan Phuong [23].

\subsection{GIS and questionnaire}

\subsubsection{Research data}

Primary and secondary data were used in the study. The primary data were acquired in a form of awareness study using survey questionnaires on June 2018 in Nam Tu Liem District. On the other hand, the secondary data that were used in the LCC detection were acquired from the United States Geological Survey (USGS) website [25].

\subsubsection{Data collection}

a. Data collection for Land cover change

An observational research design was used in the LUC study which includes both quantitative and qualitative data type. The qualitative data were acquired by the classification and alteration of LCC. On the other hand, the quantitative data were acquired by the calculation of particular area changes.

Satellite images, specifically the Landsat TM 5, Landsat 7 ETM+, and Landsat 8 OLI/TIRS having 30 by 30 spatial resolutions were all used for the three consecutive years, 2007, 2013, and 2017. The Landsat images used in the study are the accessible data having less cloud cover, which lands on May 2007, May 2013, and June 2017. The detailed descriptions of each collected satellite image are listed in Table 1 below.

\section{b. Data collection for awareness study}

A descriptive research design was used in the LCC awareness part of the study. There are two types of questionnaires used in the study: one in English language and one in a translated version of Vietnamese. The survey questionnaire covers a multiple choice, multi-response, and filter questions. It contains questions relating to the interviewees' general information and their perception towards the changes. It also contains a consent letter regarding their honesty in answering the survey to conclude that the gathered survey data would be authentic and reliable to use. The questions in the survey are formulated based on several assessments done by Neupane (2016) [26] and The Geauga County Planning Commission (2008) [27].

Table 1. Detailed description of collected satellite images

\begin{tabular}{cccccccc}
\hline S.N. & $\begin{array}{c}\text { Satellite } \\
\text { image }\end{array}$ & Sensor & Path/Row & $\begin{array}{c}\text { Number } \\
\text { of bands }\end{array}$ & $\begin{array}{c}\text { Image } \\
\text { Quality }\end{array}$ & $\begin{array}{c}\text { Cloud } \\
\text { Cover }(\%)\end{array}$ & $\begin{array}{c}\text { Date of } \\
\text { acquisition }\end{array}$ \\
\hline 1 & Landsat 5 & TM & $127 / 45$ & $1-7$ & $7 / 10$ & 1 & $2007-05-24$ \\
2 & Landsat 7 & ETM+ & $127 / 45$ & $1-9$ & $9 / 10$ & 21 & $2013-05-16$ \\
3 & Landsat 8 & OLI/TIRS & $127 / 45$ & $1-11$ & $9 / 10$ & 5.54 & $2017-06-04$ \\
\hline
\end{tabular}


Then, it was run into face validity and pretesting. A quota sample of 100 respondents were surveyed from a total of 10,706 selfemployed or individual workers. Three groups were surveyed: wholesale and retail services (48 respondents), accommodation and catering services (18 respondents), and other services (34 respondents). Furthermore, the population statistics were all acquired in Hanoi Statistical Office [24].

In line with the study references about Hanoi regarding HMP, it is assumed by the author that LCC have been happening around Hanoi and that includes the Nam Tu Liem District. The LCC map was already made prior to the interview. The LCC map wasn't shown to the interviewee for a few reasons: to see if the interviewees' perceptions are matched with the change detection study; and to see if the LCC was evident and visible for the interviewees' point of view.

\subsubsection{Data analysis}

\section{a. Detection of land cover change}

GIS, specifically, the ArcGIS software and ENVI Software were used as an instrument for the change detection. In order to make a change detection map, pre-process method was done which includes layer stack, gap fill (Landsat 7), and image subset. Radiometric process [28] and Dark Object Subtraction Method [29] were also done in this step to enhance the classification accuracy of the map $[28,30]$.

Supervised classification method is used in the study. Then, a maximum likelihood classification was applied. Table 2 shows the list of assigned land cover classes in the study. Moreover, indices such as NDVI, NDBI, NDWI, and BSI were used as a base in assigning land cover classes in each cell [31].

Before the final step which is overlaying maps, an accuracy assessment was applied in the classified image of each year: 2007, 2013, and 2017 in order to check the reliability of the map [32]. The accuracy assessment used were the User's Accuracy, Producer's Accuracy, Overall Accuracy, and Kappa Coefficient, which are then analyzed using Excel Software.
Table 2. Land Cover classes and its specification

\begin{tabular}{lll}
\hline S.N. & Class Name & Description \\
\hline 1 & Water & $\begin{array}{l}\text { Lake, river, reservoir, and } \\
\text { ponds } \\
\text { Exposed soil such as } \\
\text { uncultivated lands } \\
\text { Trees and pastures } \\
\text { Crop fields, and fallow } \\
\text { lands } \\
\text { Residential, commercial, } \\
\text { industrial, and roads }\end{array}$ \\
\hline
\end{tabular}

\section{b. Survey data analysis}

The survey data obtained from 100 respondents in Nam Tu Liem District were all inputted in Statistical Package for Social Science software (SPSS version 23) to analyze the data. The analysis used in this descriptive part of the study is strategic analysis in which univariate and bivariate analysis were both included.

\section{Results and discussions}

\subsection{Land cover change detection}

\section{a. Land cover classification}

The land cover classification of Nam $\mathrm{Tu}$ Liem District comprises of five land cover classes, including areas of water, bare land, vegetation, agriculture, and built-up. The land cover map of Nam Tu Liem District for the years 2007, 2013, and 2017 are shown in Figure 1, whereas the area and percentage of the land cover for each year are shown in Table 3 . The result indicates that the built-up area has already been on the rise since 2007 and it is also considered as the dominant land type since 2007 until 2017. On the other hand, the agriculture land type has been declining by $11.70 \%$ (375.99 hectares) and has been experiencing a drastic change throughout the years. The water, bare land, and vegetation types have shown slight changes from 2007 to 2017 which almost remain at constant. In addition, during 2007 to 2013, the water and vegetation have shown almost no changes, while bare land have decreased only by $1.68 \%$. Overall, all the land types have decreased from 2007 to 2017, excluding built-up land which have increased by $18.71 \%$ (601 hectares). 


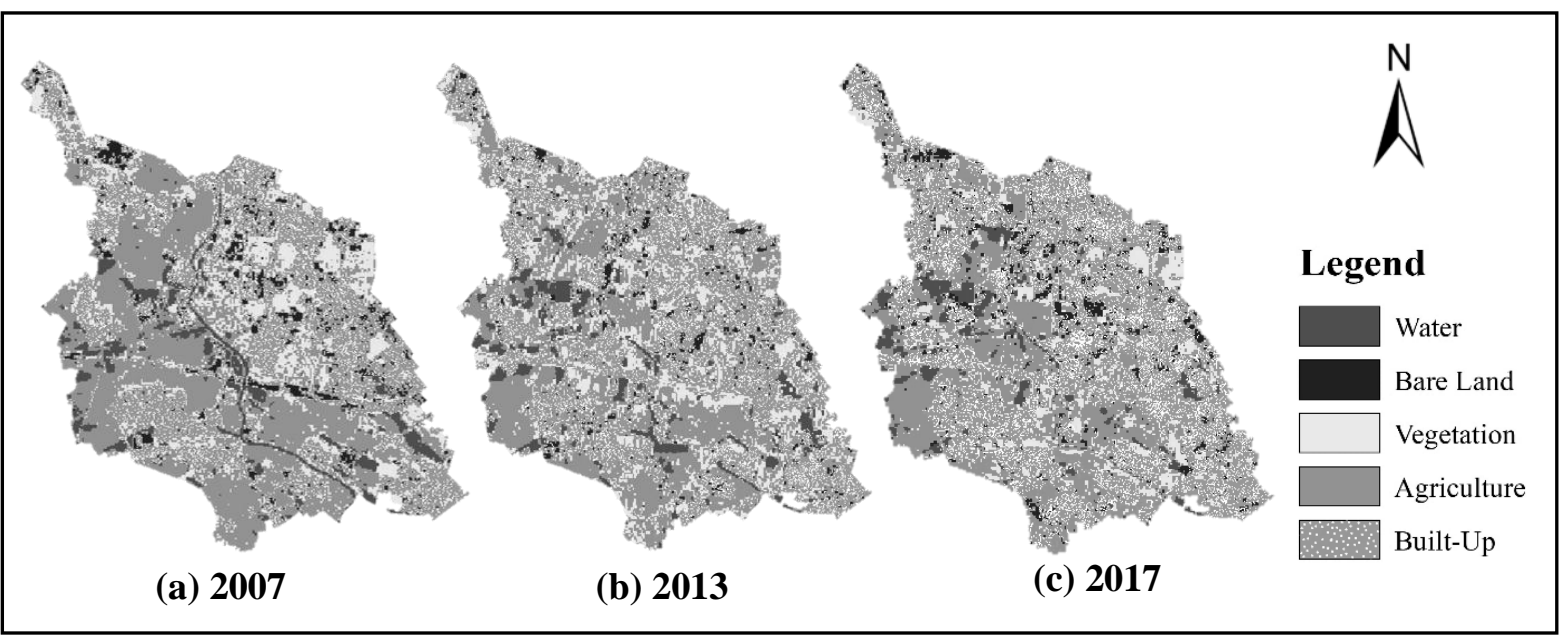

Fig. 1. The land cover figures of Nam Tu Liem district in 2007, 2013, 2017.

Table 3. The land cover classes' area and percentage in hectares

\begin{tabular}{ccccccc}
\hline & \multicolumn{2}{c}{2007} & \multicolumn{2}{c}{2013} & \multicolumn{2}{c}{2017} \\
\cline { 2 - 7 } & $\begin{array}{c}\text { Area } \\
(\text { ha })\end{array}$ & $\begin{array}{c}\text { Percentage } \\
(\%)\end{array}$ & $\begin{array}{c}\text { Area } \\
(\text { ha) }\end{array}$ & $\begin{array}{c}\text { Percentage } \\
(\%)\end{array}$ & $\begin{array}{c}\text { Area } \\
(\text { ha })\end{array}$ & $\begin{array}{c}\text { Percentage } \\
(\%)\end{array}$ \\
\hline Water & 210.33 & 6.54 & 212.89 & 6.62 & 183.49 & 5.71 \\
Bare land & 134.555 & 4.19 & 80.51 & 2.51 & 111.62 & 3.47 \\
Vegetation & 508.295 & 15.82 & 522.62 & 16.26 & 332.56 & 10.35 \\
Agriculture & 1063.06 & 33.08 & 778.74 & 24.23 & 687.07 & 21.38 \\
Built-Up & 1297.87 & 40.38 & 1618.38 & 50.35 & 1899.08 & 59.09 \\
\hline
\end{tabular}

\section{b. Land cover change detection}

The Land Cover Change Detection was done in order to analyze and determine the changes or conversions of a particular land cover class to another. The land cover class conversions from 2007 to 2013,2013 to 2017, and 2007 to 2017 are shown in Table 4 . The result shows that the built-up area has been the dominant land from 2007 to 2013, 2013 to 2017, and 2007 to 2017 having $33.14 \%, 43.64 \%$, and $35.87 \%$, respectively. Furthermore, the major land cover conversions during 2007 to 2017 includes changes from agriculture to built-up by $9.46 \%$, vegetation to built-up by $8.28 \%$, agriculture to vegetation by $4.65 \%$, and bare land to built-up by $3.26 \%$. Bare land and water areas that are converted from other land cover class shows slight changes. Moreover, areas that are converted to water area are mainly reservoir, and ponds. Whereas, bare lands are mainly uncultivated land and exposed soil.

In continuation to the major land cover conversions, agriculture to built-up land has increased during 2007 to 2017 from 5.93\% (190.30 ha) to $9.46 \%$ (303.53 ha). Likewise, the area changes from vegetation to built-up have also increased by $6.36 \%$ (203.91 ha) to $8.28 \%$ (265.40 ha) during the same year. On the other hand, the area changes from agriculture to vegetation have decreased from $6.55 \%$ (210.14 ha) to $4.65 \%$ (148.98 ha). Overall, the built-up land has already invaded $59.09 \%$ of Nam Tu Liem land, which area is 1899.08 ha during 2017. It is then followed by agriculture which have decreased by $11.70 \%$ (375.99 ha) mainly due to its conversion to built-up land. In addition, the gains and losses in each class from 2007 to 2017 are listed in Table 5. 
Table 4. Major Land Cover Class Conversions from 2007, 2013, and 2017

\begin{tabular}{|c|c|c|c|c|c|c|}
\hline \multirow[b]{2}{*}{$\begin{array}{l}\text { Land Cover Class } \\
\text { Conversions }\end{array}$} & \multicolumn{2}{|c|}{$2007-2013$} & \multicolumn{2}{|c|}{$2013-2017$} & \multicolumn{2}{|c|}{$2007-2017$} \\
\hline & $\begin{array}{c}\text { Area } \\
\text { Change } \\
\text { (ha) }\end{array}$ & $\begin{array}{l}\text { Percentage } \\
(\%)\end{array}$ & $\begin{array}{c}\text { Area } \\
\text { Change } \\
\text { (ha) }\end{array}$ & $\begin{array}{l}\text { Percentage } \\
(\%)\end{array}$ & $\begin{array}{c}\text { Area } \\
\text { Change } \\
\text { (ha) }\end{array}$ & $\begin{array}{l}\text { Percentage } \\
\quad(\%)\end{array}$ \\
\hline Water to Bare land & 3.20 & 0.10 & 4.44 & 0.14 & 6.29 & 0.20 \\
\hline Water to Vegetation & 26.05 & 0.81 & 17.41 & 0.54 & 18.62 & 0.58 \\
\hline Water to Agriculture & 29.11 & 0.91 & 35.21 & 1.10 & 40.68 & 1.27 \\
\hline Water to Built-Up & 58.65 & 1.83 & 60.50 & 1.89 & 71.31 & 2.22 \\
\hline Bare land to Water & 2.10 & 0.07 & 0.46 & 0.01 & 2.33 & 0.07 \\
\hline Bare land to Vegetation & 18.60 & 0.58 & 0.52 & 0.02 & 7.67 & 0.24 \\
\hline Bare land to Agriculture & 1.77 & 0.06 & 0.32 & 0.01 & 7.11 & 0.22 \\
\hline Bare land to Built-Up & 98.86 & 3.08 & 61.52 & 1.92 & 104.41 & 3.26 \\
\hline Vegetation to Water & 13.10 & 0.41 & 17.28 & 0.54 & 6.20 & 0.19 \\
\hline Vegetation to Bare land & 9.86 & 0.31 & 15.44 & 0.48 & 24.50 & 0.76 \\
\hline Vegetation to Agriculture & 121.69 & 3.79 & 140.75 & 4.39 & 91.56 & 2.86 \\
\hline Vegetation to Built-Up & 203.91 & 6.36 & 216.28 & 6.74 & 265.40 & 8.28 \\
\hline Agriculture to Water & 80.49 & 2.51 & 44.14 & 1.38 & 82.53 & 2.57 \\
\hline Agriculture to Bare land & 3.02 & 0.09 & 20.38 & 0.64 & 33.41 & 1.04 \\
\hline Agriculture to Vegetation & 210.14 & 6.55 & 128.58 & 4.01 & 148.98 & 4.65 \\
\hline Agriculture to Built-Up & 190.30 & 5.93 & 156.67 & 4.89 & 303.54 & 9.46 \\
\hline Built-Up to Water & 24.29 & 0.76 & 26.02 & 0.81 & 19.17 & 0.60 \\
\hline Built-Up to Bare land & 51.31 & 1.60 & 53.50 & 1.67 & 34.38 & 1.07 \\
\hline Built-Up to Vegetation & 107.98 & 3.37 & 54.15 & 1.69 & 37.30 & 1.16 \\
\hline Built-Up to Agriculture & 48.33 & 1.51 & 81.73 & 2.55 & 54.11 & 1.69 \\
\hline
\end{tabular}

Overall changes shown that built-up gained the most land (744.66 ha) and agriculture lost the most land (568.46 ha).

\subsection{Worker's perception}

As seen and observed in section aligned with the references mentioned in introduction, changes in LCC have really occurred in the district. To see if the LCC is evident, study about worker's perception was done and gathered from 100 interviewees.

In studying the worker's perception towards LCC, study findings revealed that 69\% (69 respondents) are aware about $\mathrm{LCC}$ in the district, and $31 \%$ (31 respondents) are not.

There are several questions that are intended only for the aware respondents; particularly, the $69 \%$ of the respondents. One question inquires the source of awareness of the respondent towards LCC (Table 6). Majority of the respondents' awareness comes from the local television channels $(27.8 \%$ or 45 responses), internet (25.9\% or 42 responses), and by own observation (21\% or 34 responses). Moreover, the result indicates that a total of $76.8 \%$ (53 aware respondents) are satisfied about the changes, however, a total of $23.2 \%$ (16 aware respondents) are not satisfied by the changes within the district. 
Table 5. Gains and losses by each class between 2007 and 2017

\begin{tabular}{lccc}
\hline 2007-2017 & $\begin{array}{c}\text { No } \\
\text { changes } \\
\text { (ha) }\end{array}$ & $\begin{array}{c}\text { Area } \\
\text { Gains } \\
\text { (ha) }\end{array}$ & $\begin{array}{c}\text { Area } \\
\text { Losses } \\
\text { (ha) }\end{array}$ \\
\hline Water & 72.69 & 110.23 & 136.90 \\
Bare Land & 12.85 & 98.58 & 121.52 \\
Vegetation & 119.52 & 212.57 & 387.66 \\
Agriculture & 492.51 & 193.46 & 568.46 \\
Built-Up & 1150.33 & 744.66 & 144.96 \\
\hline
\end{tabular}

Table 6. Source of LCC awareness

\begin{tabular}{lcc}
\hline \multicolumn{1}{c}{ Sources } & $\mathrm{N}$ & $\begin{array}{c}\text { Percent } \\
(\%)\end{array}$ \\
\hline Local Television Channels & 45 & 27.8 \\
Local Radio Channels & 11 & 6.8 \\
Local Press & 3 & 1.9 \\
Internet & 42 & 25.9 \\
Posters & 2 & 1.2 \\
Brochures & 2 & 1.2 \\
Village Meetings & 3 & 1.9 \\
Teacher & 2 & 1.2 \\
Neighbors/Friends & 18 & 11.1 \\
As observed & 34 & 21.0 \\
\hline \multicolumn{1}{c}{ Total } & 162 & 100.0 \\
\hline
\end{tabular}

In continuation, the 69 aware respondents were asked about the impacts of LCC in their business; $92.8 \%$ or 64 respondents stated that it is all positive, however, $7.2 \%$ respondents stated that it has a negative impact to their business.

On the contrary, the aware respondents were also asked about the LCC benefits. The results indicate that the majority believes that LCC is for the country's and the district's own good for the future. Moreover, the study also includes an intended question for the aware respondents regarding the continuous changes in the district. A total of $82.6 \%$ aware respondents want changes to continue, however, $17.4 \%$ aware respondents do not want changes to continue. The reasons for these are listed in Table 7 and 8 .

As sight on the respondent's view towards the LCC pressure towards their business and living, the aware respondents were able to determine the major problems in the district that has been happening that are mostly brought by LCC and urbanization. The responses centered around three major problems: Overpopulation, congestion and poor waste management having $20 \%, 17.9 \%$, and $17.4 \%$ responses, respectively. In addition, these three major problems were followed by pollution problems which also have a large percentage ha $15.9 \%$ or 31 responses.

Table 7. Respondents who want changes to continue

\begin{tabular}{|c|c|c|}
\hline Yes & $\mathrm{N}$ & $\begin{array}{l}\text { Percent } \\
(\%)\end{array}$ \\
\hline $\begin{array}{l}\text { Increase the employment } \\
\text { opportunities }\end{array}$ & 14 & 13.2 \\
\hline Reduce the poverty & 28 & 26.4 \\
\hline $\begin{array}{l}\text { More developments } \\
\text { phenomena }\end{array}$ & 20 & 18.9 \\
\hline To change the lifestyle & 39 & 36.8 \\
\hline Others & 5 & 4.7 \\
\hline Total & 106 & 100.0 \\
\hline
\end{tabular}

Table 8. Respondents who don't want changes to continue

\begin{tabular}{lcc}
\hline \multicolumn{1}{c}{ No } & $\mathrm{N}$ & $\begin{array}{c}\text { Percent } \\
(\%)\end{array}$ \\
\hline $\begin{array}{l}\text { To keep our culture } \\
\begin{array}{l}\text { Environmental } \\
\text { Degradation }\end{array}\end{array}$ & 6 & 24.0 \\
$\begin{array}{l}\text { Negative impacts on the } \\
\text { biodiversity }\end{array}$ & 5 & 20.0 \\
$\begin{array}{l}\text { Pressured food supply } \\
\text { High cost of living }\end{array}$ & 1 & 16.0 \\
$\begin{array}{l}\text { Do not like to change the } \\
\text { lifestyle }\end{array}$ & 7 & 4.0 \\
\hline Total & 2 & 8.0 \\
\hline
\end{tabular}

Furthermore, there are questions that are intended for the overall respondents, including both aware and unaware respondents. Questions contain security and satisfaction of the respondents towards the changes and developments in their district. In terms of safety and security, $89 \%$ of the respondents feel safe in their wards, and $11 \%$ do not. On the other hand, in terms of satisfaction towards developments, $86 \%$ of the respondents are satisfied, and $14 \%$ are not. 
Table 9. Changes that the respondents would like to see in the district

\begin{tabular}{lccccc}
\hline & \multicolumn{2}{c}{ Aware $(69 \%)$} & Unaware (31\%) & $\begin{array}{c}\text { Total } \\
(100 \%)\end{array}$ \\
\cline { 2 - 4 } Changes respondents would like to see in the future & $\mathrm{N}$ & $\begin{array}{c}\text { Percentage } \\
(\%)\end{array}$ & $\mathrm{N}$ & $\begin{array}{c}\text { Percentage } \\
(\%)\end{array}$ & $\begin{array}{l}\text { (10) } \\
\text { More residential development }\end{array}$ \\
Provision of central water and sewer services & 25 & 36.23 & 10 & 32.26 & 35 \\
Closer shopping opportunities & 8 & 24.64 & 7 & 22.58 & 24 \\
Closer employment opportunities & 23 & 33.33 & 10 & 32.26 & 33 \\
More open space, parks, outdoor recreation, scenic areas, etc. & 32 & 46.38 & 10 & 32.26 & 42 \\
Preservation of farms & 4 & 5.80 & 1 & 3.23 & 5 \\
More rigorous zoning enforcement & 16 & 23.19 & 3 & 9.68 & 19 \\
Development of town center & 12 & 17.39 & 5 & 16.13 & 17 \\
Establish a historic district & 5 & 7.25 & 2 & 6.45 & 7 \\
None & 8 & 11.59 & 6 & 19.35 & 14 \\
Others & 1 & 1.45 & 0 & 0 & 1 \\
\hline Response Total & 151 & 218.84 & 62 & 200 & 213 \\
\hline
\end{tabular}

Respondents were asked if there is/are something they would like to change or see to develop in their wards and the whole district in the future. The number of responses from both aware and unaware respondents are shown in Table 9. Majority (42\%) wants more open space like parks, outdoor recreation, and scenic areas, followed by more residential development $(35 \%)$, and closer employment opportunities (33\%). Moreover, majority of the aware respondents want more open space $(46.38 \%)$ ). On the other hand, the responses of the unaware respondents centered around three choices which are more residential development, more open space, and closer employment opportunities $(32.26 \%)$. Furthermore, around $14 \%$ of the respondents picked none which is assumed that they are already contented with the changes around the district. Moreover, from the aware respondents' point of view, it is assumed that they may have already seen and experienced the consequences that LCC brought from the past years. Lastly, the individual workers' income status was asked. The $71 \%$ of the respondents said it became better, $28 \%$ stated that nothing has changed, and $1 \%$ said the it became worse over 10 years.

The awareness of respondents may be affected by several factors including their level of education, years of residency, and more that will not be tackled or a scope in this study. As analyzed in Table 10, the percentage of unaware respondents is higher in University Level (61.29\%) compared to Senior Highschool $(38.71 \%)$. Likewise, the percentage of aware respondents is also higher in University Level (59.42\%). Overall, there are $60 \%$ respondents that completed University level and 36\% respondents that completed Senior Highschool. Moreover, there are 4\% respondents that only completed Junior Highschool which are reported to be aware about changes in the district (Table $10)$.

In terms of residency (Table 11), it is found out that only $37 \%$ of the respondents are originally from Nam Tu Liem District and 63\% are just migrants which came from different provinces like Thai Binh, Nam Dinh, Nghe An, and other districts of Hanoi, such as Hoai Duc, $\mathrm{Ba} \mathrm{Vi}$, and Ha Dong. From a total of 69 aware respondents, the results show that there are $44.93 \%$ respondents that are originally from the district and $55.07 \%$ respondents are not.

Moreover, majority of the aware respondents have already been residing to the district for over 20 years $(44.93 \%)$. Regardless, about $39.13 \%$ of the aware respondents have only been residing for months to 5 years (Table 12). 
Table 10. The respondent's education level

\begin{tabular}{clcccc}
\hline & \multicolumn{3}{c}{ Aware } & \multicolumn{3}{c}{ Unaware } \\
\cline { 2 - 5 } A2. Level of Education & $\mathrm{N}$ & $\begin{array}{l}\text { Percentage } \\
(\%)\end{array}$ & $\mathrm{N}$ & $\begin{array}{l}\text { Percentage } \\
(\%)\end{array}$ & Total \\
\hline Junior Highschool & 4 & 5.80 & 0 & 0 & 4 \\
Senior Highschool & 24 & 34.78 & 12 & 38.71 & 36 \\
College/University Level & 41 & 59.42 & 19 & 61.29 & 60 \\
\hline Total & 69 & 100 & 31 & 100 & 100 \\
\hline
\end{tabular}

Table 11. Number of unaware and aware respondents which are residents and migrants in Nam Tu Liem district

\begin{tabular}{clllll}
\hline $\begin{array}{c}\text { Are you originally } \\
\text { from Nam Tu Liem? }\end{array}$ & $\mathrm{N}$ & Percent $(\%)$ & $\mathrm{N}$ & $\begin{array}{l}\text { Percent } \\
(\%)\end{array}$ & Total \\
\cline { 2 - 6 } & 31 & 44.93 & 6 & 19.35 & 37 \\
Yes & 38 & 55.07 & 25 & 80.65 & 63 \\
\hline No & 69 & 100 & 31 & 100 & 100 \\
\hline Total & & & &
\end{tabular}

Table 12. Duration of the respondent's residency

\begin{tabular}{clllll}
\hline $\begin{array}{c}\text { How long have you resided } \\
\text { in Nam Tu Liem? }\end{array}$ & $\mathrm{N}$ & $\begin{array}{l}\text { Percentage } \\
(\%)\end{array}$ & $\mathrm{N}$ & $\begin{array}{c}\text { Percentage } \\
(\%)\end{array}$ & Total \\
\cline { 2 - 5 } & 27 & 39.13 & 24 & 77.42 & 51 \\
\hline 0 to 5 years & 9 & 13.04 & 2 & 6.46 & 11 \\
6 to 10 years & 2 & 2.90 & 0 & 0 & 2 \\
11 to 20 years & 31 & 44.93 & 5 & 16.13 & 36 \\
Over 20 years & 69 & 100 & 31 & 100 & 100 \\
\hline Total & &
\end{tabular}

Furthermore, there are 31 respondents that are not aware towards LCC happenings in the district. It is assumed in the study that reasons might be because of the non-evident and unnoticeable land use changes in the district. Also, the outcomes might also be just a result of the ignorance of the residents. Moreover, findings indicate that the majority of unaware respondents are not originally from the district $(80.65 \%)$ and have only been residing for only months to 5 years $(77.42 \%)$ (Table 11 and 12$)$.

Moreover, the factors that affect the individual's awareness towards LCC may also affect other aspects. For example, the level of education, duration of residency, how long the business is running, choice of business etc. could affect their income status. Another example is how income could affect individual's education which has an influence on the business choice. Moreover, business choice could also affect the individual's source of income by how high demands are for that business which could also influence the worker's view towards land use change. However, these scenarios are not considered as a part of the study in any further extent.

\subsection{Mitigation}

By the continuous expansion of urban areas and built-up lands along with rising population, it may result in environmental degradation and socio-economic problems. In addition, there are 
several solutions for mitigating undesirable impacts brought by the LULCC that could be applied in Nam Tu Liem District. It includes decent urban planning and management for fighting urban heat [33, 34], well-planned arrangement of trees in the city [6], combatting congestion and pollution by banning motorbikes in Hanoi [21], upgrading road networks and rail station [6].

Other social and standard of living problems in context of surroundings, facilities, and services which includes poor infrastructure, poor waste management, pollution, and health problems will all be covered and mitigated by the decent land use planning and assessments by the legislators, planners, and government officials [35]. Moreover, it is assumed by the researcher that the solutions and mitigations of LCC impacts may have a relation about how the society will react to a certain problem as sometimes they are one of the drivers of such factors. However, this will not be a scope of this study and will be highly recommended for further study. Additionally, it is already expected that the unfamiliarity, ignorance, insensitiveness, as well as the awareness of the society towards land use could contradict with the land use plans. Thus, public perception and participation are really significant for the land use planning. An example of this is by studying and considering the individual's interests, needs, and requests to have a vision of what the community wants to see in the future (Table 9). One previous study confirms that in able to achieve sustainable development, the plans and development of an area should reflect and match to the needs and requests of the local community [36]. Moreover, some individuals are lacking knowledge about land use/land cover change in which could cause unfamiliarity of its potent impacts to their ways of living, their surroundings, the environment, etc. By this scenario, government efforts are proximately desired. With simple knowledge about the existing world problem trends along with the proper attitudes by the society towards LULCC and its impacts, policies for the land use and environment would be desirably implemented.

\section{Conclusion}

With the use of RS and GIS technology, the land cover analysis was completed in a lower cost and a lesser time with a greater accuracy. The main study's goals are to analyze the land use change in Nam Tu Liem District in 2007 to 2017 and to have an overview about the selfemployed worker's awareness towards changes in the district.

Major findings shown that built-up area in Nam Tu Liem District has been on the rise since 2007 and assumed to be happening on previous years. Also, it has been the dominant land since 2007 and remained one until 2017. On the other hand, agriculture has been observed to be declining which is mainly converted to built-up land. Same goes as well with the declining land for the vegetation class. Moreover, bare land and water have also lost hectares of land which are converted to other classes, such as for urban and agriculture purposes. However, bare land and water area have shown only slight changes within 2007 to 2017. Overall, all of the land cover types have decreased during 2007 to 2017, except for the built-up area which has invaded $59.09 \%$ or 1899.08 ha of Nam Tu Liem land in 2017.

Furthermore, the findings for the study about land cover change awareness indicate that about two-thirds or a total of $69 \%$ of respondents are aware of LCC happenings in the district. However, almost one-third or $31 \%$ are unaware of the said topic. There are several factors that may affect the respondent's awareness towards LCC, such as level of education, and duration of residency; however, it can also be stated that lack of awareness may be a cause of ignorance in some aspects. The land use change could affect the businesses positively or negatively which could also have an influence on the worker's perception towards it. This study cannot conclude that the said factors really have a significant relationship with the respondent's awareness since further analysis and scientific studies must be done. 
This study is considered as one of the steps and the initial enquiry in determining and understanding land use/land cover changes' major drivers and impacts in Nam Tu Liem District's environment, as well as the society and its demands in the future. Furthermore, this study could open more new issues and scenarios in the district to be studied and monitored in the succeeding years.

\section{Recommendations}

The land use/cover in Nam Tu Liem District and the entire region of Hanoi, Vietnam will keep on changing for the next succeeding years, mainly because of the Hanoi Master Plan 2030 and Vision to 2050. These developments and changes in Nam $\mathrm{Tu}$ Liem will bring both negative and positive impacts on different aspects; therefore, it is highly recommended to have a detailed study about the land use/land cover change (significant relation and interaction to its impact) and an updated and a larger society perception towards changes in Nam Tu Liem District in the succeeding years. It is suggested in order for the researchers to keep up with the past and current happenings in the district, as well as it is significant for prediction studies and policy making. By analyzing land use/cover change and studying perception, it would be uncomplicated to find achievable solutions and effective ways to lessen the undesirable consequences of changes in land use and make the best use of it.

\section{Acknowledgments}

The study was done under Advanced Education Program in Thai Nguyen University of Agriculture and Forestry. The author would like to acknowledge the kind support and cooperation provided by the staffs of AEP, colleagues, and supervisors.

\section{References}

[1] M.A. Mahamud, N. Samat, N.M. Noor, Identifying factors influencing urban spatial growth for the George Town Conurbation, Journal of the Malaysian Institute of Planners 14 (5) (2016) 95106. https://doi.org/10.21837/pmjournal.v14.i5.186.

[2] Q.H. Vuong, Vietnam's Political Economy: A discussion on the 1986-2016 period. Centre Emile Bernheim Working Paper, $\mathrm{N}^{\circ} 14 / 010$. University Libre de Bruxelles, Brussels: Belgium, 2014. https://doi.org/10.2139/ssrn.2439809.

[3] World Bank, East Asia's Changing Urban Landscape: Measuring a Decade of Spatial Growth. World Bank; Washington, DC, USA, 2015.

[4] General Statistics Office of Vietnam, The 2014 Viet Nam Intercensal Population and Housing Survey: Major Findings, Statistical Documentation and Service Center, Hanoi, Vietnam, 2014.

[5] Vietnam Institute of Architecture Urban and Rural Planning, The Hanoi Capital Construction Master Plan 2030 and Vision to 2050, Comprehensive Report, VIAP, Hanoi, Vietnam, 2011.

[6] A.R. Trihamdani, T. Kubota, H.S. Lee, K. Sumida, T.T.T. Phuong. Impacts of land use changes on urban heat islands in Hanoi, Vietnam: Scenario analysis. Procedia Engineering 198 (2017) 525-529. https://doi.org/10.1016/j.proeng. 2017.07.107.

[7] T. Hoang, New green area for Hanoi. Vietnam Economic Times, 2015. http://vneconomictimes. com/article/property/new-green-area-for-hanoi. (Accessed 20 March 2018).

[8] J.S. Rawat, M. Kumar, Monitoring land use/cover change using remote sensing and GIS techniques: A case study of Hawalbagh block, district Almora, Uttarakhand, India, The Egyptian Journal of Remote Sensing and Space Sciences 18 (2015) 7784. https://doi.org/10.1016/j.ejrs. 2015. 02.002.

[9] Partoyo, R.P. Shrestha, Modeling Effect of Conservation and Livelihood Policies on Community Land Use and Management in Yogyakarta. In: Redefining Diversity \& Dynamics of Natural Resources Management in Asia 1 (2017) 67-90. https://doi.org/10.1016/B978-0-12-8054543.00005-0.

[10] P. Journeaux, E. van Reenen, T. Manjala, S. Pike, I. Hanmore, Analysis of Drivers and Barriers to Land Use Change. Hamilton, NZ: AgFirst Waikato Ltd., 2017.

[11] B. Zondag, J. Borsboom. Driving Forces of LandUse Change. Paper prepared for the 49th ERSA conference, Lodz, Poland, 2009. 
[12] M.G. Turner, C.L. Ruscher, Change in landscape patterns in Georgia. USA Landscape Ecology 1 (4) (2004) 251-421.

[13] W. Steffen, R.A. Sanderson, P.D. Tyson, J. Jäger, P.A. Matson, B. Moore III, F. Oldfield, K. Richardson, H.J. Schellnhuber, B.L. Turner II, R.J. Wasson, Global Change and the Earth System: A Planet Under Pressure. Berlin: Springer, 2004. https://doi.org/10.1007/B137870.

[14] B.L. Turner II, E.F. Lambin, A. Reenberg, The emergence of land change science for global environmental change and sustainability. Proceedings of the National Academy of Sciences of the United States of the America 104 (52) (2007) 20666-20671. https://doi.org/10.1073/pnas.07041 19104.

[15] A.A. Belal, F.S. Moghanm, Detecting Urban Growth Using Remote Sensing and GIS Techniques in Al Gharbiya Governorate, Egypt. The Egyptian Journal of Remote Sensing and Space Science 14 (2011) 73-79. https://doi.org/10. 1016/j.ejrs.2011.09.001.

[16] J. Wu, Land Use Changes: Economic, Social, and Environmental Impacts. Choices 23 (4) (2008) 610. http://www.choicesmagazine.org/UserFiles/ file/article_49.pdf. (Accessed 04 April 2018).

[17] G. Xu, L. Jiao, S. Zhao, M. Yuan, X. Li, Y. Han, B. Zhang, T. Dong, Examining the Impacts of Land Use on Air Quality from a Spatio-Temporal Perspective in Wuhan, China. Atmosphere 7 (5) (2016) 62. https://doi.org/10.3390/atmos7050062.

[18] H. Zhang, Z.-F. Qi, X.-Y. Ye, Y.-B. Cai, W.-C. Ma, M.-N. Chen. Analysis of land use/land cover change, population shift, and their effects on spatiotemporal patterns of urban heat islands in metropolitan Shanghai China. Applied Geography 44 (2013) 121-133. https://doi.org/10.1016/j. apgeog.2013.07.021.

[19] M. Moore, P. Gould, B.S. Keary, Global Urbanization and Impact on Health. International Journal of Hygiene and Environmental Health 206 (2003) 269-278. https://doi.org/10.1078/1438 4639-00223.

[20] D.A. Leon. Cities, urbanization and health. International Journal of Epidemiology 37 (1) (2008) 4-8. https://doi.org/10.1093/ije/dym271.

[21] Japan International Cooperation Agency. The Comprehensive Urban Development Programme in Hanoi Capital City of the Socialist Republic of Vietnam (HAIDEP): Master Plan Study. Final Report, 2007. http://open_jicareport.jica.go.jp/618/ 618/618_123_11856101.html (Accessed 13 March 2018).

[22] K.J.H. Williams, J. Schirmer, Understanding the relationship between social change and its impacts:
The experience of rural land use change in southeastern Australia. Journal of Rural Studies 28 (4) (2012) 538-548. https://doi.org/10.1016/j. jrurstud. 2012.05.002.

[23] Nhan Dan. Hanoi has two new districts: Bac Tu Liem, Nam Tu Liem, 2013. http://en.nhandan.com. vn/society/item/2186002-hanoi-has-two-newdistricts-bac-tu-liem-nam-tu-liem.html (Accessed 20 March 2018)

[24] Hanoi Statistical Office. Statistical Yearbook of 2017. Statistics Office of Nam Tu Liem District, 2017.

[25] United States Geological Survey (USGS). www.earthexplorer.usgs.gov (Accessed 30 March 2018)

[26] K. Neupane, An Assessment of Land Use Land Cover Change in Barandabhar Forest Corridor, Chitwan District, Nepal. Bachelor of Science in Forestry Degree. Tribhuvan University, Kathmandu Forestry College, Kathmandu, Nepal, 2016.

[27] The Geauga County Planning Commission. Newbury Township Geauga County, Ohio Land Use Plan, 2008. http://www.newburyohio.com/ BusinessFiles/NewburyTwp_MasterPlan.pdf. (Accessed 26 March 2018)

[28] N. Horning, Land cover classification methods. American Museum of Natural History, Center for Biodiversity and Conservation, 2004. http:// biodiversityinformatics.amnh.org. (Accessed 03 March 2018)

[29] P.S. Chavez Jr. An improved dark-object subtraction technique for atmospheric scattering correction for multispectral data. Remote Sensing of Environment 24 (1988) 459-479. https://doi. org/10.1016/0034-4257(88)90019-3.

[30] C. Song, C.E. Woodcock, K.C. Seto, M.P. Lenne, S.A. Macomber. Classification and Change Detection Using Landsat TM Data: When and How to Correct Atmospheric Effects? Remote Sensing of Environment 75 (2) (2001) 230-244. https:// doi.org/10.1016/S0034-4257(00)00169-3.

[31] F. Mwakapuja, E. Liwa, J. Kashaigili, Usage of Indices for Extraction of Built-up Areas and Vegetation Features from Landsat TM Image: A Case of Dar Es Salaam and Kisarawe Peri-Urban Areas, Tanzania. International Journal of Agriculture and Forestry 3 (7) (2013) 273-283. https://doi.org/ 10.5923/j.ijaf.20130307.04.

[32] G.A. Banko, Review of Assessing the Accuracy of Classifications of Remotely Sensed Data and of Methods Including Remote Sensing Data in Forest Inventory. Interim Report IR-98-081. International Institute for Applied Systems Analysis (IIAA). Laxenburg, Austria, 1998. 
[33] D.G. Brown, C. Polsky, P. Bolstad, S.D. Brody, D. Hulse, R. Kroh, T.R. Loveland, A. Thomson, Land use and land cover change. In: J. M. Melillo, T. C. Richmond, and G. W. Yohe (eds) Climate Change Impacts in the United States, The Third National Climate Assessment. US Global Change Research Program, 2014, 318-332. https:// doi.org/10.7930/ J05Q4T1Q.

[34] M. Maimaitiyiming, A. Ghulam, T. Tiyip, F. Pla, P. Latorre-Carmona, Ü. Halik, and S. Caetano. Effects of green space spatial pattern on land surface temperature: Implications for sustainable urban planning and climate change adaptation, ISPRS Journal of Photogrammetry and Remote
Sensing 89 (2014) 59-66. https://doi.org/10.1016/ j.isprsjprs.2013.12.010.

[35] J.R. Anderson, E.E. Hardy, J.T. Roach, R.E. Witmer. A land use and land cover classification system for use with remote sensor data. U.S. Geological Survey Professional Paper, No. 964. USGS, Washington, D.C., 1976. https://doi.org/ 10.3133/pp964.

[36] Y.A.E. Elhadary, N. Samat, F. Obeng-Odoom. Development at the Peri-Urban Area and Its Impact on Agricultural Activities: An Example from the Seberang Perai Region, Penang State, Malaysia. Agroecology and Sustainable Food Systems 37 (7) (2013) 834-856. https://doi.org/ 10.1080/21683565. 2013.797950. 